\title{
ANALISIS VARIABEL OPERASIONAL YANG BERPENGARUH TERHADAP EFISIENSI OPERASIONAL BANK PERKREDITAN RAKYAT (BPR) WILAYAH MALANG
}

Oleh:

Irmayanti Hasan*

\begin{abstract}
Efficiency is important to industrial banking because since released the prudent deregulation of banking have growing new banks and making tight competitions on the industrial of bank. Not including if linked with existence of bank that must take or put outside fund where will given return on investment for survival live in future. So efficiency is important item to noticing. The operational variables influenced toward efficiency talked about are savings, total loan, total of spread value and total intermediate cost.

This research aimed to know amount of savings, loan, amount of spread value, amount intermediate cost and degree efficiency of Bank Perkreditan Rakyat $(B P R)$ in Malang district.

The method to taking sample using Purposive Sampling Type Judgement Sampling is the method-taking sample with belonging non-probabilities where the selection based certain criteria is obtained 22 numbers BPR as sample by means of research periods 3 years (2001-2004) at the BPR in Malang areas. The analysis data used descriptive analysis and inferential statistic analysis, is the multiple regression analysis-using program Statistic Package for Social Science (SPSS) ver 10.5 for Windows 2000 with level of signifikan 5\% ( $\alpha=5 \%)$.

Based result of descriptive analysis, funded that amount of savings, amount of loans, amount of spread value, amount of intermediate cost, and degree of efficiency ever of Bank Perkreditan Rakyat (BPR) in Malang areas as long as period of research begin 2001 to 2004 are to much variation between one of BPR with other.
\end{abstract}

Key words : Variabel-variabel opera sional, Efisiensi operasional, BPR. 


\section{PENDAHULUAN}

\section{Latar Belakang}

Keberadaan Bank Perkreditan Rakyat (BPR) memang cukup menarik untuk disoroti mengingat keberadaannya banyak bersentuhan dengan kegiatan ekonomi golongan menengah ke bawah yang notabene merupakan sektor kegiatan ekonomi yang menjanjikan dan menentukan. Disamping itu, BPR juga lebih terbuka dan transparan dalam memberikan informasi-informasi tertentu yang dibutuhkan untuk mendukung penelitian.

Keberadaan industri perbankan (dalam hal ini BPR) yang jumlahnya semakin meningkat menuntut masing-masing bank (BPR) untuk merencanakan dan menetapkan strategi-strategi yang tepat guna memenangkan persaingan diantara bank (BPR) yang lain. Jika tidak demikian hanya tinggal menghitung kapan saat terjadi kebangkrutan pada bank (BPR) yang bersangkutan (Yavas and Donald, 1997;105). Sejalan dengan pendapat demikian, Tjoekam(1999;25) menyatakan:

"Pada kondisi dimana persaingan antar BPR semakin ketat, menuntut masing-masing BPR untuk membuat strategi operasional yang lebih baik sehingga bisa tetap mempertahankan bahkan dapat meningkatkan kepercayaan masyarakat serta mampu mencapai keuntungan yang mencukupi”.

Efisiensi menjadi bagian yang sangat penting dalam operasional suatu usaha, terlebih lagi bagi lembaga-lembaga keuangan seperti BPR mengingat dalam operasinya pihak-pihak tersebut juga mengeluarkan sejumlah dana yang tidak sedikit. Jika tidak bisa mengefisienkan operasinya maka dalam masa yang 
akan datang akan menderita kepailitan atau kebangkrutan. Belum lagi jika dihadapkan dengan faktor persaingan antar BPR, tentunya menuntut masingmasing BPR untuk dapat mengefisienkan operasi usahanya.

Konsep efisiensi dapat dijadikan sebagai suatu tolok ukur atau indikator penilian dari kelangsungan hidup suatu usaha, yang pada gilirannya akan mempengaruhi keputusan investasi di masa yang akan datang. (Riyanto,1995: 86).

Besarnya tingkat efisiensi BPR, terlebih dulu perlu diketahui beberapa variabel yang mempengaruhinya. "Variabel operasional seperti kredit atau pinjaman, simpanan, dan biaya intermediasi mempunyai kontribusi yang tinggi dalam penilaian efisiensi bank perkreditan rakyat sehingga memerlukan pengaturan yang optimal” (Sukarno, 2000;35).

Pengukuran efisiensi yang digunakan adalah dengan menggunakan cara sebagaimana telah dijelaskan pada sajian di atas karena penghitungannya lebih praktis, sederhana dan mudah. Di samping itu pada sajian laporan keuangan dari beberapa bank yang dilaporkan pada khalayak umum melalui media massa seperti majalah atau surat kabar, dalam pengukuran efisiensinya juga menggunakan cara sebagaimana yang dimaksudkan dalam Ketentuan Surat Edaran Bank Indonesia tersebut.

Berangkat dari uraian diatas dalam penelitian ini akan dikaji mengenai variabel-variabel operasional yang berpengaruh terhadap efisiensi BPR di wilayah Malang. 


\section{Identifikasi Masalah}

1. Bagaimana deskripsi mengenai jumlah simpanan, pinjaman, spread, biaya intermediasi, dan tingkat efisiensi operasional BPR di wilayah Malang?

2. Apakah jumlah simpanan, pinjaman, spread, dan biaya intermediasi secara parsial maupun simultan mempunyai pengaruh yang signifikan terhadap tingkat efisiensi operasional BPR di wilayah Malang?

3. Dari variabel jumlah simpanan, pinjaman, spread, dan biaya intermediasi, variabel manakah yang paling dominan pengaruhnya terhadap tingkat efisiensi operasional BPR di wilayah Malang?

\section{Tujuan Penelitian}

1. Untuk mendeskripsikan mengenai jumlah simpanan, pinjaman, spread, biaya intermediasi, dan tingkat efisiensi operasional BPR di wilayah Malang?

2. Untuk mengetahui pengaruh jumlah simpanan, pinjaman, spread, dan biaya intermediasi terhadap tingkat efisiensi operasional Bank Perkreditan Rakyat BPR di wilayah Malang secara parsial maupun simultan?

3. Untuk mengetahui variabel manakah diantara jumlah simpanan, pinjaman, spread, dan biaya intermediasi yang paling dominan pengaruhnya terhadap tingkat efisiensi operasional BPR di wilayah Malang?

\section{Manfaat Penelitian}

1. Manfaat Praktis, dari hasil penelitian ini nantinya dapat memberikan masukan bagi pihak manajemen BPR di wilayah Malang dalam penentuan kebijakan operasionalnya, terutama dalam kebijakan pengaturan simpanan dan pinjaman 
seperti mengenai jangka waktunya, jumlahnya, jenisnya, serta tingkat suku bunga yang ditetapkan. Pada sisi lain juga dapat memberikan masukan kepada pihak manajemen BPR untuk mengetahui variabel yang paling dominan pengaruhnya terhadap efisiensi operasional BPR sehingga menjadi perhatian yang serius dalam pengelolaan operasional BPR.

2. Manfaat Teoritis, hasil penelitian ini dapat menjadi input yang berguna bagi pengembangan ilmu pengetahuan mengenai manajemen keuangan, khususnya mengenai penentuan kebijakan dalam operasional ind ustri perbankan.

3. Manfaat Bagi Peneliti Lain, hasil penelitian ini dapat digunakan sebagai bahan referensi untuk penelitian lebih lanjut terutama bagi pihak-pihak yang berkepentingan.

\section{METODE PENELITIAN}

\section{Jenis Penelitian}

Sesuai dengan tujuan penelitian yang ingin dicapai, maka penelitian ini termasuk dalam jenis penelitian explanatory (penjelasan). Singarimbun dan Effendi (1987:5) menyatakan bahwa penelitian penjelasan (explanatory research) adalah penelitian yang menjelaskan hubungan kausal antara variabel-variabel penelitian melalui pengujian hipotesis.

\section{Populasi dan Sampel}

Obyek yang dipilih dalam penelitian ini adalah BPR di wilayah Malang dengan periode penelitian antara tahun 2001 sampai dengan tahun 2004 atau selama 3 tahun. 
Dasar pertimbangan dalam memilih BPR di lokasi ini adalah:

1. Secara regional wilayah Malang merupakan sentra kegiatan ekonomi kedua di Jawa Timur serta mempunyai tingkat perputaran uang relatif tinggi.

2. Tingkat persaingan antar bank di wilayah Malang sangat tinggi dibandingkan dengan wilayah lain, karena banyak terdapat bank-bank besar, baik bank pemerintah maupun swasta sehingga menuntut masingmasing bank, termasuk BPR untuk dapat beroperasi dengan tingkat efisiensi yang tinggi.

3. Data yang diperlukan beserta data pendukung lainnya relatif lebih mudah untuk diperoleh mengingat jangkauan wilayahnya tidak terlalu luas sehingga bisa dihindari terjadinya pemalsuan data sehingga hasil penelitian lebih akurat dan memberikan manfaat yang berarti.

4. Disamping itu obyek yang diteliti sampai saat ini belum pernah dilakukan penelitian dengan kajian yang sama.

\section{Sumber Data}

Data yang diperlukan dalam penlitian ini meliputi:

1. Data primer dapat diperoleh dengan menghubungi langsung pada BPRBPR terkait untuk meminta informasi yang dibutuhkan, utamanya mengenai variabel-variabel yang terkait dan kaji dalam penelitian ini.

2. Data skunder diperoleh dengan menghubungi instansi yang terkait dengan penelitian ini, di antaranya yaitu Bank Indonesia Malang yang merupakan pusat kendali dan pengawasan dari beberapa bank yang berada dalam 
wilayah kerjanya. Dalam hal ini BPR-BPR di wilayah Malang berada dalam wilayah kerja Bank Indonesia Malang.

\section{Identifikasi Variabel}

Bank dikategorikan efisien dalam operasionalnya apabila mempunyai profit margin $(P M)$, yaitu pengukuran efisiensi melalui perbandingan antara laba operasional dibagi dengan pendapatan minimum sebesar 8 prosen. Sedangkan melalui pengukuran Return on Assets (ROA), yaitu pengukuran efisiensi melalui perbandingan antara laba operasional dibagi dengan total aktiva, suatu bank dikatakan sehat apabila besarnya ROA minimum 1,5 prosen.

Foster $(1988 ; 52)$ juga menyatakan "ukuran efisiensi dapat dinilai dari operating profit margin (PM), dan Return on Total Assets (ROA)”. Secara lebih lanjut dinyatakan bahwa profit margin $(P M)$ mengukur tingkat efisiensi dari kemampuan BPR dalam menghasilkan laba dari operasi usahanya. Profit margin merupakan rasio antara laba sebelum pajak dengan pendapatan operasinya. Semakin besar rasio ini dimiliki oleh BPR, maka akan semakin baik, karena secara teoritis berarti semakin besar laba yang diperoleh dari hasil operasinya.

Laba sebelum pajak

profit margin $(P M)=$

Pendapatan operasi

(Foster,1988;55). 
Return on Assets (ROA) menunjukan kemampuan suatu bank dalam mengelola aktiva yang dimilikinya untuk mendapatkan laba. Dengan kata lain, ROA merupakan ukuran dari efisiensi dalam pengelolaan segenap kekayaan yang dimiliki untuk mendapatkan laba yang optimal. ROA merupakan perbandingan antara laba sebelum pajak dengan total aktiva. Semakin besar rasio ini, bararti suatu usaha dapat dikatakan semakin baik kondisinya, karena secara teoritis ROA merupakan muara muara dari aktiva produktif yang berkualitas dari manajemen yang solid.

Laba sebelum pajak

Return on assets $(\mathrm{RO} A)=$

Total aktiva

(Foster, 1988;56).

Apabila dirumuskan, tingkat efisiensi operasional perbankan (BPR) adalah sebagai berikut:

Biaya Operasional

Tingkat efisiensi operasional $=$

Pendapatan Opersnal

(SE BI No. 26/6/BPP/93 tanggal 29 Mei 1993)

Dalam hal ini, efisiensi operasional dapat diketahui cukup hanya dengan membagi biaya oprasional suatu bank dengan pendapatan operasionalnya. Dalam Ketentuan Surat Edaran ditetapkan bahwa dalam pengukuran ini, suatu bank dikatakan efisien bila besarnya efisiensi maksimum $92 \%$. Hal ini berarti 
bahwa bank dengan biaya operasional kurang dari atau sama dengan 92\% dari pendapatan operasionalnya, bank dapat dikategorik an beroperasi secara efisien.

\section{Analisis dan Teknik Pengolahan Data}

Teknik pengolahan data yang dipergunakan dalam penelitian ini adalah regresi berganda. Regresi berganda digunakan untuk mengetahui pengaruh keseluruhan variabel bebas terhadap variabel terikat. Pengolahan datanya dilakukan dengan menggunakan bantuan komputer dengan software khusus statistik, yaitu Program Statistical Package for Social Science (SPSS) Versi 10.5. for Windows 2000.

\section{HASIL PENELITIAN DAN PEMBAHASAN}

\section{Deskripsi Hasil Penelitian}

\section{Jumlah Simpanan}

Berdasarkan data penelitian dapat diketahui bahwa jumlah simpanan yang diterima oleh BPR terdiri atas jumlah tabungan, jumlah deposito berjangka, jumlah simpanan dari bank lain, dan jumlah simpanan dari pihak lain. Jumlah dari keseluruhan jenis simpanan merupakan jumlah simpanan yang diterima. Selama periode penelitian, jumlah simpanan tertinggi adalah sebesar Rp 281.096.191.000,- sedangkan jumlah simpanan terendah adalah sebesar Rp 76.167.000,-. Selama periode penelitian, rata-rata jumlah simpanan penelitian sebesar Rp 13.502.853.28,- . 


\section{Jumlah Pinjaman}

Dari data penelitian dapat diketahui bahwa jumlah kredit atau pinjaman yang diberikan dikelompokkan menjadi dua jenis, yaitu jumlah pinjaman ke bank lain dan kredit yang diberikan kepada masyarakat umum. Jumlah dari kedua jenis pinjaman tersebut menjadi jumlah keseluruhan kredit atau pinjaman yang diberikan. Jumlah pinjaman yang diberikan oleh BPR sampel selama periode penelitian sangat beragam antara BPR satu dengan BPR yang lain. Jumlah pinjaman yang diberikan tertinggi adalah sebesar Rp 478. 299.899.000,sedangkan jumlah pinjaman terkecil adalah sebesar Rp 111.377.000,-. Melihat data yang demikian dapat dibayangkan betapa ketatnya persaingan di antara BPR dalam pengelolaan operasi usahanya. Sedangkan rata-rata jumlah pinjaman selama periode penelitian sebesar Rp 19.213.837.924,-

\section{Jumlah Nilai Spread}

Spread adalah selisih antara pendapatan bunga yang diterima oleh suatu bank dengan biaya bunga yang dikeluarkan dalam suatu periode tertentu yang nilainya biasanya dinyatakan dalam prosentase (UU No. 10 Tahun 1998 tentang perubahan UU No. 7 tahun 1992 tentang perbankan). Nilai spread yang dinyatakan dalam prosentase sebenarnya menunjukkan selisih antara suku bunga pinjaman dengan suku bunga simpanan.

Nilai spread dari BPR sampel selama periode penelitian juga sangat variatif antara BPR satu dengan BPR yang lain. Hal ini mengindikasikan bahwa kemampuan pengelolaan usaha dan manajerial dari masing-masing bank juga berbeda, sedangkan rata-ratanya sebesar $8 \%$. Pada dasarnya kemampuan 
pengelolaan usaha dan manajerial tersebutlah yang dipersaingkan di antara masing-masing BPR. Barang siapa mempunyai kemampuan manajerial yang baik, tentunya akan memenangkan persaingan itu.

\section{Jumlah Biaya Interme diasi}

Biaya intermediasi muncul berkaitan dngan fungsi utama bank sebagi lembaga perantara keuangan (financial mediatory). Biaya intermediasi adalah yaitu semua biaya yang dikeluarkan oleh bank (dalam hal ini BPR) selain biaya bunga berkaitan dengan fungsi dan perannya sebagai lembaga perantara keuangan (financial mediatory) selama periode teretentu. Biaya-biaya tersebut di antaranya: biaya premi asuransi, biaya gaji, upah, dan honorarium tenaga kerja, biaya pendidikan tenaga kerja, biaya lainnya tenaga kerja, biaya sewa, biaya pajak-pajak (selain pajak penghasilan), biaya pemeliharaan dan perbaikan, biaya ph atau penyusutan aktiva produktif, biaya ph atau penyusutan aktiva tetap dan inventaris, biaya penyusutan atau penghapusan beban yang ditangguhkan, biaya barang dan jasa, serta biaya operasional yang lain.

Besar kecilnya biaya intermediasi tersebut juga dipengaruhi oleh banyak sedikitnya jasa bank yang ditawarkan kepada masyarakat/nasabah. Kontraprestasi dari biaya ini adalah pendapatan operasional, selain pendapatan bunga. Dari data penelitian dapat diketahui bahwa jumlah biaya intermediasi dari masing-masing BPR sampel terdapat keragaman antara BPR yang satu dengan BPR yang lain. Jumlah biaya intermediasi terbesar mencapai jumlah sebesar Rp 1.240.986.250,sedangkan biaya intermediasi terendah mencapai jumlah sebesar Rp 8.145.000,-. Sedangkan rata-rata jumlah biaya intermediasinya sebesar Rp 133.219.835,-. 


\section{Efisiensi Operasional B PR}

Dalam penelitian ini efisiensi operasional perbankan (BPR) diukur menurut ketentuan yang dinyatakan dalam Surat Edaran Bank Indonesia No. 26/6/BPP/93 tanggal 29 Mei 1993 dihitung dengan cara membagi biaya operaional dengan pendapatan operasional, atau dalam kalangan perbankan lebih akrab dengn sebutan BOPO (Biaya Operasional, Pendapatan Operasional). Pada pengukuran ini, bank dikatakan efisien bila biaya opersional maksimum $92 \%$ dari pendapatan yang diperoleh pada periode yang bersangkutan.

Berdasarkan data penelitian, dan setelah dilakukan perhitungan dapat diketahui bahwa efisiensi dari masing-masing BPR sampel dalam penelitian ini juga bervariasi antara BPR yang satu dengan BPR yang lain. Ada beberapa BPR yang nilai efisiensinya kurang dari $92 \%$ tetapi ada juga yang nilai efisiensi melebihi $92 \%$ sebagaimana batasan maksimum yang dikriteriakan oleh Bank Indonesia.

\section{Hasil Analisis Regresi Berganda}

Untuk mengetahui pengaruh variabel-variabel operasional bank dengan efisiensinya, dapat dilakukan dengan menggunakan analisis regresi berganda (multiple) yang digunakan untuk mengetahui peringkat pengaruh masing-masing variabel bebas terhadap variabel terikat. Dalam hal ini yang menjadi variabel terikat adalah efisiensi BPR, sedangkan yang menjadi variabel bebasnya adalah variabel-variabel operasional BPR yang terdiri atas: jumlah pinjaman, simpanan, spread, dan biaya intermediasi. Rumus persamaan regresii yang dipakai sebagai berikut (Sudjana, 1992;45): 


$$
Y=b_{0}+b_{1} X_{1}+b_{2} X_{2}+b_{3} X_{3}+b_{4} X_{4}+e
$$

Dimana:

$$
\begin{array}{ll}
\mathrm{Y} & =\text { Tingkat Efisiensi } \\
\mathrm{X}_{1} & =\text { Jumlah Simpanan } \\
\mathrm{X}_{2} & =\text { Jumlah Pinjaman } \\
\mathrm{X}_{3} & =\text { Jumlah Spread } \\
\mathrm{X}_{4} & =\text { Jumlah Biaya intermediasi } \\
\mathrm{b}_{0} & =\text { Intercept atau konstanta } \\
\mathrm{b}_{1}-\mathrm{b}_{4} & =\text { Disturbance error atau variabel pengganggu } \\
\mathrm{e} &
\end{array}
$$

Setelah dilakukan perhitungan dengan menggunkan bantuan komputer melalui software Program Statistical Package for Social Science (SPSS) Versi 10.5 for Windows 2000 dapat diperoleh hasil regresi. dapat dilihat bahwa:

a. Nilai Sig F sebesar 0,000 yang berarti bahwa hipotesis (Ha diterima) artinya bahwa berdasarkan hasil penelitian, secara simultan variabelvariabel jumlah simpanan $\left(\mathrm{X}_{1}\right)$, jumlah pinjaman $\left(\mathrm{X}_{2}\right)$, jumlah spread $\left(\mathrm{X}_{3}\right)$, dan jumlah biaya intermediasi $\left(\mathrm{X}_{4}\right)$ berpengaruh secara signifikan terhadap tingkat efisiensi (Y).

b. Nilai koefisien determinasi (Adjusted R Square) adalah sebesar 0,859 yang berarti bahwa variabel efisiensi BPR dipengaruhi sebesar $85,9 \%$ oleh variabel jumlah simpanan $\left(\mathrm{X}_{1}\right)$, jumlah pinjaman $\left(\mathrm{X}_{2}\right)$, jumlah spread $\left(\mathrm{X}_{3}\right)$, dan jumlah biaya intermed iasi $\left(\mathrm{X}_{4}\right)$, sedangkan sisanya $14,1 \%$ dipengaruhi oleh variabel lain diluar ke-4 variabel bebas yang diteliti. 
c. Berdasarkan pengujian hipotesis tersebut diperoleh persamaan regresi mengenai pengaruh variabel-variabel jumlah simpanan, jumlah pinjaman, jumlah spread, dan jumlah biaya intermediasi terhadap variabel efisiensi BPR sebagai berikut:

$Y=19,65+8,27.10^{-8} X_{1}-2,50 \cdot 10^{-8} X_{2}+1.35 X_{3}+2,59 \cdot 10^{-7} X_{4}+e$

Berdasarkan hasil analisis regresi berganda pada tabel di atas dapat diketahui bahwa $\mathrm{R}$ sebesar 0,932 , berarti bahwa terdapat pengaruh yang signifikan antara variabel-variabel bebas jumlah simpanan $\left(\mathrm{X}_{1}\right)$, jumlah pinjaman $\left(\mathrm{X}_{2}\right)$, jumlah spread $\left(\mathrm{X}_{3}\right)$, dan jumlah biaya intermediasi $\left(\mathrm{X}_{4}\right)$ secara simultan terhadap variabel efisiensi BPR (Y). Nilai Adjusted R Square sebesar 0,859 berarti kontribusi semua varaibel- variabel bebas tersebut terhadap keragaman variabel Y (efisiensi BPR) adalah sebesar 85,9\%, sedangkan sisanya sebesar $14,1 \%$ dipengaruhi oleh faktor lain yang tidak termasuk ke dalam model.

Untuk menguji pengaruh yang signifikan antara variabel-variabel bebas jumlah simpanan $\left(\mathrm{X}_{1}\right)$, jumlah pinjaman $\left(\mathrm{X}_{2}\right)$, jumlah spread $\left(\mathrm{X}_{3}\right)$, dan jumlah biaya intermediasi $\left(\mathrm{X}_{4}\right)$ secara simultan terhadap variabel efisiensi BPR (Y) digunakan uji F.

Dominasi pengaruh variabel bebas terhadap variabel terikat ditentukan dari nilai absolut $\mathrm{B}$ atau nilai mutlak Beta yang paling besar. Alternatif lain yang dapat digunakan untuk mengetahui variabel mana yang paling dominan pengaruhnya terhadap efisiensi BPR dapat dilihat dari kontribusi variabel bebas terhadap variabel terikat yaitu dengan memperhatikan nilai koefisien determinasi $\left(\mathrm{r}^{2}\right)$. Variabel yang mempunyai nilai koefisien determinasi $\left(\mathrm{r}^{2}\right)$ yang paling besar 
merupakan variabel yang mempunyai pengaruh paling dominan terhad ap efisiensi BPR.

\section{Pengujian Hipotesis}

Sebagiamana telah diuraikan pada bagian sebelumnya bahwa Uji-F, digunakan untuk menghitung signifikansi nilai koefisien determinasi yang telah diperoleh dengan menggunakan analisis variance, yaitu untuk mengetahui apakah secara simultan (bersama-sama) koefisien regresi variabel bebas mempunyai pengaruh terhadap variabel tergantung atau tidak.

Untuk mengetahui hipotesis diterima atau ditolak, dengan cara membandingkan antara nilai $\mathrm{F}_{\text {-hitung }}\left(\mathrm{F}_{\mathrm{h}}\right)$ dengan nilai $\mathrm{F}_{\text {-tabel }}$ pada tingkat signifikansi (tingkat kepercayaan) 5\% $(\alpha=0,05)$. Jika $\mathrm{F}_{\text {-hitung }}\left(\mathrm{F}_{\mathrm{h}}\right)>\mathrm{F}_{\text {-tabel, }}$, maka hipotesis diterima.

Dari hasil uji regresi berganda sebagaimana yang telah disajikan pada bagian sebelumnya, data dapat diketahui nilai $\mathrm{F}_{\text {-hitung }}$ sebesar 91,134 lebih besar dari $\mathrm{F}_{\text {-tabel }}$ sebesar 2,51 dengan nilai probabilitas (Sig F) 0,000. Dengan demikian berarti Hipotesis $0\left(\mathrm{H}_{\mathrm{o}}\right)$ ditolak dan Hipotesis penelitian $\left(\mathrm{H}_{\mathrm{a}}\right)$ yang berbunyi terdapat pengaruh yang signifikan antara variabel jumlah simpanan $\left(\mathrm{X}_{1}\right)$, jumlah pinjaman $\left(\mathrm{X}_{2}\right)$, jumlah spread $\left(\mathrm{X}_{3}\right)$, dan biaya intermediasi $\left(\mathrm{X}_{4}\right)$ secara simultan (bersama-sama) terhadap efisiensi BPR dapat diterima.

Uji t merupakan uji statistik atas koefisien regresi secara parsial yang digunakan untuk menguji tingkat signifikansi dari masing-masing koefisien regresi variabel bebas terhadap variabel terikat. Suatu variabel signifikan secara 
statistik apabila nilai t hitung melebihi nilai kritis pada tingkat keyakinan tertentu (Gujarati, 1995).

Dalam penelitian ini uji t digunakan untuk mengetahui seberapa besar pengaruh dan kontribusi masing-masing variabel bebas yang dimasukkan dalam model terhadap variabel terikat efisiensi BPR.

Untuk mengetahui hipotesis diterima atau ditolak, dengan cara membandingkan antara nilai $\mathrm{t}_{-}{ }_{\text {hitung }}\left(\mathrm{t}_{\mathrm{h}}\right)$ dengan nilai $\mathrm{t}_{\text {-tabel }}$ pada tingkat signifikansi (tingkat kepercayaan) 5\% $(\alpha=0,05)$. Jika $\mathrm{t}_{-}$hitung $\left(\mathrm{t}_{\mathrm{h}}\right)>\mathrm{t}_{\text {-tabel, }}$, maka hipotesis diterima. Sedangkan kontribusi masing variabel bebas terhadap variabel terikat dapat dilihat pada nilai $\mathrm{r}^{2}$ yang diperoleh.

Berdasarkan pada hasil analisis, variabel jumlah simpanan $\left(\mathrm{X}_{1}\right)$ mempunyai nilai t-hitung sebesar 2,984 lebih besar dari t-tabel sebesar 2,0041 dengan nilai probabilitas (Sig t) 0,004 yang lebih kecil dari $\alpha$ sebesar 5\% $(0,004<$ 0,05). Dengan demikian berarti Hipotesis $0\left(\mathrm{H}_{\mathrm{o}}\right)$ ditolak dan Hipotesis penelitian $\left(\mathrm{H}_{\mathrm{a}}\right)$ yang berbunyi terdapat pengaruh yang signifikan antara variabel jumlah simpanan $\left(\mathrm{X}_{1}\right)$ secara parsial terhadap efisiensi BPR $(\mathrm{Y})$ dapat diterima. Nilai koefisien regresi parsial (B) yang diperoleh adalah $8,27.10^{-8}$ maka dapat diartikan bahwa jika nilai jumlah simpanan dinaikkan sebesar satu satuan, maka nilai efisiensi akan meningkat sebesar $8,27.10^{-8}$ dengan asumsi bahwa variabelvariabel yang lain diangggap konstan. Nilai $\mathrm{r}^{2}$ yang diperoleh sebesar 9,74.10-8\% menunjukkan besarnya kontribusi pengaruh jumlah simpanan terhadap efisiensi BPR.

Berdasarkan pada hasil analisis, variabel jumlah pinjaman $\left(\mathrm{X}_{2}\right)$ mempunyai nilai t-hitung sebesar -0,888 lebih kecil dari t-tabel sebesar 2,004 dengan 
nilai probabilitas (Sig t) 0,379 yang lebih besar dari $\alpha$ sebesar $5 \%(0,379>0,05)$. Dengan demikian berarti Hipotesis $0\left(\mathrm{H}_{\mathrm{o}}\right)$ diterima dan Hipotesis penelitian $\left(\mathrm{H}_{\mathrm{a}}\right)$ yang berbunyi terdapat pengaruh yang signifikan antara variabel jumlah simpanan $\left(\mathrm{X}_{1}\right)$ secara parsial terhadap efisiensi BPR (Y) ditolak. Nilai koefisien regresi parsial (B) yang diperoleh adalah $-2,50.10^{-8}$ maka dapat diartikan bahwa jika nilai jumlah simpanan dinaikkan sebesar satu satuan, maka nilai efisiensi akan menurun sebesar $-2,50.10^{-8}$ dengan asumsi bahwa variabel-variabel yang lain diangggap konstan. Nilai $\mathrm{r}^{2}$ yang diperoleh sebesar $0,19 \%$ menunjukkan besarnya kontribusi pengaruh jumlah pinjaman terhadap efisiensi BPR.

Pada variabel ini nilai probabilitas (Sig t) 0,379 yang lebih besar dari $\alpha$ sebesar 5\% $(0,379>0,05)$ menunjukkan adanya pengaruh yang tidak signifikan antara jumlah pinjaman terhadap efisiensi, artinya pengaruh jumlah pinjaman terhadap efisiensi tersebut tidak nyata. Dari hasil analisis diketahui bahwa Nilai koefisien regresi parsial (B) yang diperoleh adalah $-2,50.10^{-8}$ maka dapat diartikan bahwa jika nilai jumlah simpanan dinaikkan sebesar satu satuan, maka nilai efisiensi akan menurun sebesar $-2,50 \cdot 10^{-8}$ dengan asumsi bahwa variabelvariabel yang lain diangggap konstan, namun karena nilai probabilitas (Sig t) 0,379 yang lebih besar dari $\alpha$ sebesar $5 \%(0,379>0,05)$ maka pengaruh tersebut tidak begitu nyata (tidak signifikan).

Berdasarkan pada hasil analisis, variabel jumlah spread $\left(\mathrm{X}_{3}\right)$ mempunyai nilai t-hitung sebesar 5,709 lebih besar dari t-tabel sebesar 2,0041 dengan nilai probabilitas (Sig t) 0,000 yang lebih kecil dari $\alpha$ sebesar 5\% $(0,000<0,05)$. Dengan demikian berarti Hipotesis $0\left(\mathrm{H}_{\mathrm{o}}\right)$ ditolak dan Hipotesis penelitian $\left(\mathrm{H}_{\mathrm{a}}\right)$ yang berbunyi terdapat pengaruh yang signifikan antara variabel jumlah spread 
$\left(\mathrm{X}_{3}\right)$ secara parsial terhadap efisiensi BPR (Y) dapat diterima. Nilai koefisien regresi parsial (B) yang diperoleh adalah 1,35 maka dapat diartikan bahwa jika nilai jumlah simpanan dinaikkan sebesar satu satuan, maka nilai efisiensi akan meningkat sebesar 1,35 dengan asumsi bahwa variabel-variabel yang lain diangggap konstan. Nilai $\mathrm{r}^{2}$ yang diperoleh sebesar $15,17 \%$ menunjukkan besarnya kontribusi pengaruh jumlah simpanan terhadap efisiensi BPR.

Berdasarkan pada hasil analisis, variabel jumlah biaya intermediasi $\left(\mathrm{X}_{4}\right)$ mempunyai nilai t-hitung sebesar 2,667 lebih besar dari t-tabel sebesar 2,0041 dengan nilai probabilitas (Sig t) 0,010 yang lebih kecil dari $\alpha$ sebesar 5\% $(0,010<0,05)$. Dengan demikian berarti Hipotesis $0\left(\mathrm{H}_{\mathrm{o}}\right)$ ditolak dan Hipotesis penelitian $\left(\mathrm{H}_{\mathrm{a}}\right)$ yang berbunyi terdapat pengaruh yang signifikan antara variabel jumlah simpanan $\left(\mathrm{X}_{1}\right)$ secara parsial terhadap efisiensi BPR (Y) dapat diterima. Nilai koefisien regresi parsial (B) yang diperoleh adalah $2,59.10^{-7}$ maka dapat diartikan bahwa jika nilai jumlah simpanan dinaikkan sebesar satu satuan, maka nilai efisiensi akan meningkat sebesar $2,59.10^{-7}$ dengan asumsi bahwa variabel-variabel yang lain diangggap konstan. Nilai $\mathrm{r}^{2}$ yang diperoleh sebesar $3,08 \%$ menunjukkan besarnya kontribusi pengaruh jumlah simpanan terhadap efisiensi BPR.

Jumlah spread menjadi variabel yang paling dominan dibandingkan dengan variael yang lain ditunjukkan oleh nilai t-hitung sebesar 5,709 lebih besar dari t-tabel sebesar 2,0041 dengan nilai probabilitas (Sig t) 0,000 yang lebih kecil dari $\alpha$ sebesar $5 \%(0,000<0,05)$. Nilai t-hitung dari variabel jumlah spread $\left(\mathrm{X}_{3}\right)$ ini merupakan yang paling besar dibandingkan dengan variabel yang lain.

Hal lain yang mendukung variabel spread menjadi variabel yang paling dominan pengaruhnya terhadap efisiensi ditunjukkan oleh nilai koefisien regresi 
parsial (B) yang paling besar dibandingkan variabel yang lain yaitu sebesar 1,35 yang dapat diartikan bahwa jika nilai jumlah simpanan dinaikkan sebesar satu satuan, maka nilai efisiensi akan meningkat sebesar 1,35 dengan asumsi bahwa variabel-variabel yang lain diangggap konstan. Hal lain yang juga mendukung ditunjukkan oleh nilai $\mathrm{r}^{2}$ yang diperoleh paling besar diantara variabel yang lain yaitu sebesar 15,17\% yang menunjukkan besarnya kontribusi pengaruh jumlah spread terhadap efisiensi BPR.

\section{Kesimpulan}

1. Jumlah simpanan, jumlah pinjaman, jumlah spread, jumlah biaya intermediasi, dan nilai efisiensi dari masing-masing Bank Perkreditan Rakyat (BPR) wilayah Malang selama periode penelitian yaitu mulai 1999-2001 sangat bervariatif antara BPR yang satu dengan BPR yang lain.

2. Berdasarkan hasil analisis dengan menggunakan uji $\mathrm{F}$ untuk membuktikan hipotesis penelitian, diperoleh hasil bahwa terdapat pengaruh yang signifikan secara simultan antara variabel-variabel operasional yang terdiri atas jumlah simpanan, jumlah pinjaman. jumlah spread, dan jumlah biaya intermediasi terhadap efisiensi Bank Perkreditan Rakyat (BPR) wilayah Malang. Sedangkan Berdasarkan hasil analisis regresi berganda dengan menggunakan uji t dapat diketahui bahwa variabel jumlah simpanan $\left(\mathrm{X}_{1}\right)$ berpengaruh positif signifikan terhadap variabel efisiensi $(\mathrm{Y})$, variabel jumlah pinjaman $\left(\mathrm{X}_{2}\right)$ berpengaruh negatif tidak signifikan terhadap variabel efisiensi (Y), variabel jumlah spread $\left(\mathrm{X}_{3}\right)$ berpengaruh positif signifikan terhadap variabel efisiensi 
(Y), dan variabel jumlah biaya intermediasi $\left(\mathrm{X}_{4}\right)$ berpengaruh positif signifikan terhadap variabel efisiensi (Y).

3. Berdasarkan hasil analisis dapat diketahui bahwa variabel jumlah spread mempunyai pengaruh yang paling dominan terhadap efisiensi dibandingkan dengan variabel bebas yang lain. Jumlah spread menjadi variabel yang paling dominan dibandingkan dengan variabel yang lain ditunjukkan oleh nilai t-hitung sebesar 5,709 lebih besar dari t-tabel sebesar 2,0041 dengan nilai probabilitas (Sig t) 0,000 yang lebih kecil dari $\alpha$ sebesar 5\% $(0,000<0,05)$. Nilai t-hitung dari variabel jumlah spread $\left(\mathrm{X}_{3}\right)$ ini merupakan yang paling besar dibandingkan dengan variabel yang lain. Dominasi yang paling besar oleh variabel Jumlah Spread pengaruhnya terhadap efisiensi BPR wilayah Malang juga ditunjukkan oleh nilai koefisien regresi parsial (B) yang paling besar dibandingkan variabel yang lain yaitu sebesar 1,35 yang dapat diartikan bahwa jika nilai jumlah simpanan dinaikkan sebesar satu satuan, maka nilai efisiensi akan meningkat sebesar 1,35 dengan asumsi bahwa variabel-variabel yang lain diangggap konstan. Hasil penelitian lain yang mendukung variabel Jumlah Spread menjadi variabel yang paling dominan pengaruhnya terhadap efisiensi ditunjukkan oleh nilai $\mathrm{r}^{2}$ yang diperoleh paling besar diantara variabel yang lain yaitu sebesar $15,17 \%$ yang menunjukkan besarnya kontribusi pengaruh jumlah spread terhadap efisiensi BPR wilayah Malang.

\section{Saran}

1. Pihak manajerial BPR wilayah Malang perlu memperhatikan kriteria yang berkaitan dengan kelayakan kredit (the " $5 C^{\prime \prime}$ of credit) sebelum diputuskan 
pemberian kredit sehingga dapat dihindari terjadinya kredit macet atau bermasalah yang nantinya akan mengakibatkan turunnya efisiensi BPR. Jangan hanya karena ingin memenangkan persaingan, lalu kemudian terlalu lunak dan kurang selektif di dalam menilai kelayakan kredit kepada para calon peminjam tetapi perlu mengkaji efeknya dalam jangka penjang berkaitan dengan pengembalian kredit yang diberikan. Hal ini perlu disampaikan mengingat dari hasil penelitian nampak bahwa jumlah pinjaman mempunyai pengaruh negatif terhadap efisiensi meskipun tidak signifikan dimana hal tersebut salah satunya adalah disebabkan oleh kurang hati-hati dalam keputusan pemberian kredit/pinjaman.

2. Pihak manajerial BPR wilayah Malang perlu memperhatikan dengan serius terhadap masalah spread, dan berusaha sedemikian rupa untuk mendapatkan spread yang positif agar efisiensinya dapat ditingkatkan. Hal ini disarankan mengingat dari hasil penelitian nampak bahwa variabel bebas spread merupakan variabel yang paling dominan pengaruhnya terhadap efisiensi dibandingkan dengan variabel bebas yang lain.

3. Pihak manajerial BPR wilayah Malang hendaknya dapat mengoptimalkan fungsi bank sebagai lembaga perantara keuangan, dimana jasa yang diberikan tidak sebatas pelayanan simpanan dan pinjaman tetapi dapat juga memberikan jasa-jasa lain yang relevan sehingga dapat memberikan kontribusi pendapatan selain pendapatan bunga dengan sedapat mungkin menekan biaya intermediasinya. Dengan demikian pihak BPR akan mendapatkan pendapatan operasional lain selain pendapatan bunga yang pada akhirnya akan dapat meningkatkan efisiensinya. Hal ini disarankan mengingat dari hasil penelitian 
nampak bahwa semakin besar biaya intermediasi yang dikeluarkan maka semakin besar pula efisiensi yang dicapai. 


\section{DAFTAR PUSTAKA}

Bank Indonesia. Panduan Penyusunan Laporan Perbankan: Standar Khusus Akuntansi Perbankan Indonesia (SKAPI) dan Pedoman Akuntansi Perbankan Indonesia (PAPI).

Bringham, Eugene F; and Weston, J Fred. 1991. Essentials of Managerial Finance. Sevent Edition. Prentice Hall Inc. London.

Cooper, D. R. ang Emory, C. W. 1996. Metode Penelitian Bisnis. Alih Bahasa: Gunawan E dan Nurmawan. Jilid I. Erlangga. Jakarta.

Fess, Philips E, and Niswonger, Rollin C. 1992. Prinsip-Prinsip Akuntansi. Terjemahan. Penerbit Binarupa Aksara. Jakarta.

Foster, George. 1988. Financial Statement Analysis. Second Edition. Englewood Cliffs. Prentice-Hall Inc. New Jersey. P. 67.

Ikatan Akuntan Indonesia (IAI). 1994. Standar Akuntansi Indonesia. Edisi Revisi 2. Rineka Cipta. Jakarta:

Livingstone, John Leslie. 1992. The Portable MBA in Finance and Accounting. Edisi Terjemahan. Binarupa Aksara. Jakarta

Mulyono, Teguh Pudjo. 1995. Analisa Laporan Keuangan untuk Perbankan. Edisi Revisi III. Penerbit Djambatan. Jakarta.

Paket Kebijakan Pemerintah Tanggal 27 Oktober 1988 (Pakto'88) tentang Deregulasi Sektor Perbankan Nasional. Jakarta: Bank Indonesia.

Peraturan Bank Indonesia No. 03/15/PBI/2001 mengenai Penetapan Status BPR dalam Pengawasan Khusus dan Pembekuan Kegiatan Usaha.

Rahardjo, Pratama. 1990. Pasar Modal Indonesia, Lembaga Pengembangan Perbankan Indonesia. Penerbit Gramedia. Jakarta.

Riyanto, Bambang. 1995. Dasar-Dasar Pembelanjaan Perusahaan. Edisi 4. BPFE. Yogyakarta.

Santoso, Prihanto Sigit. 2000. Pengaruh Simpanan, Total Kredit, Pendapatan Lainnya dan Total Assets terhadap Pendapatan BRI Area Mikro Surabaya Kaliasin Unit Mastrip. Tesis Program Pascasarjana Universitas 17 Agustus Surabaya.

Santoso, Ruddy Tri. 1994. Manajemen Bank Umum. Manajemen Bank Umum. Intermedia. Jakarta. 
Sartono, A. 1996. Manajemen Keuangan Teori dan Aplikasi. Edisi ketiga. Cetakan keempat. BPFE. Yogyakarta.

Singarimbun, Masri dan Effendi. 1987. Metode Penelitian Bisnis. LP3ES. . Jakarta.

Sinungan, M. 1994. Strategi Manajemen Bank (Menghadapi Tahun 2000). Penerbit Rineka Cipta. Jakarta.

Sudjana. 1992. Teknik Analisis Regresi an Korelasi. Penerbit Tarsito. Bandung.

Sugiyono. 1999. Metode Penelitian Administrasi. Penerbit Alfabet. Bandung

Sukarno, Imam. 2000. Kiat BPR Menghadapi Awal Milenium Ketiga. Jurnal Pengembangan Perbankan. Jan - Peb. No. 81, hal 35 - 39.

Supranto, J. 1986. Pengantar Probabilita dan Statistik Induktif. Jilid 2. Erlangga. Jakarta.

Suara Merdeka. 1997. Efisiensi Perbankan Nasional. Suplemen Ekonomi Bisnis Suara Merdeka. Edisi 28 April 1997. Hal: 14.

Surat Edaran Bank Indonesia No. 26/6/BPPP tanggal 29 Mei 1993 tentang Pengukuran Efisiensi Perbankan Nasional.

Suyatno, Thomas dan Azhar, Abdullah. 1993. Kelembagaan Perbankan. Edisi Ketiga. Penerbit Gramedia. Jakarta.

Tjoekam, Moh. 1999. Perkreditan: Bisnis Inti Bank Komersial. Gramedia. Jakarta.

Undang-Undang Pokok Perbankan No. 14 Tahun 1967.

Undang-Undang No. 7 tahun 1992 tentang Perbankan.

Undang-Undang No. 10 tahun 1998 tentang Perbankan.

Weston, J Fred and Copeland, Thomas, E. 1992. Manajemen Keuangan. Edisi Kedelapan. Terjemahan. Penerbit Binarupa Aksara. Jakarta.

Wilner, Benjamin S. 2000. The Exploitation of Relationships in Financial Distress: The Case of Trade Credit. Journal of Finance. Vol. 55, Iss: 1.

* Irmayanti Hasan, MM., Dosen Fakultas Ekonomi UIN Malang 
